\title{
CSF Presenilin-1 complexes are increased in Alzheimer's disease
}

\author{
María-Salud García-Ayllón 1,2,3, María-Letizia Campanari 1,2, Gunnar Brinkmalm4, Alberto Rábano 2,5, Jordi Alom², \\ Carlos A Saura ${ }^{2,7}$, Niels Andreasen ${ }^{8}$, Kaj Blennow ${ }^{4}$ and Javier Sáez-Valero ${ }^{1,2^{*}}$
}

\begin{abstract}
Background: Presenilin-1 (PS1) is the active component of the amyloid precursor protein cleaving $\gamma$-secretase complex. PS1 protein is a transmembrane protein containing multiple hydrophobic regions which presence in cerebrospinal fluid (CSF) has not been measured to date. This study assesses whether PS1 and other components of the $y$-secretase complex are present in CSF.

Results: Here, we show that PS1 is present in ventricular post-mortem and lumbar ante-mortem CSF, and plasma as 100-150-kDa hetero-complexes containing both the N- and C-terminal fragments (NTF and CTF) of the protein. Immunoprecipitation and immunoblotting with different antibodies confirmed the identity of the PS1 species. The $\gamma$-secretase components, APH-1 (anterior pharynx-defective 1) and PEN-2 (presenilin enhancer 2), as well as presenilin-2 (PS2) fragments, co-exist within these CSF complexes, while nicastrin is not detected. These CSF-PS1 complexes differ from active $\gamma$-secretase membrane-complexes, and may represent nonspecific aggregation of the PS1 protein. Levels of PS1 complexes are increased in CSF samples from autopsy-confirmed Alzheimer's disease (AD) cases and were found to be more stable than complexes in CSF from control subjects. Despite similar levels of total PS1 in CSF from probable AD patients and cognitively normal subjects, an increased proportion of highly stable PS1 complexes were observed in AD CSF.
\end{abstract}

Conclusions: Our data suggest that fragments of the PS1 protein present in CSF as complexes may be useful as a biomarker for AD.

Keywords: Alzheimer's disease, Cerebrospinal fluid, Diagnostic, Biomarker, Presenilin 1

\section{Background}

The major pathological hallmarks of Alzheimer's disease $(\mathrm{AD})$, the $\beta$-amyloid peptide $(\mathrm{A} \beta)$ and the abnormally hyperphosphorylated protein tau (P-tau), are also recognized biomarkers which have been extensively investigated (for a review see [1]). However, there is a continuing search for new cerebrospinal fluid (CSF) biomarkers for use in clinical diagnosis, especially for the early stages of $\mathrm{AD}$, and for use in clinical trials.

Other logical AD biomarker candidates are proteins involved in the pathological processing of the large transmembrane protein, the amyloid precursor protein (APP),

\footnotetext{
* Correspondence: j.saez@umh.es

${ }^{1}$ Instituto de Neurociencias de Alicante, Universidad Miguel Hernández-CSIC,

Av. Ramón y Cajal s/n, Sant Joan d'Alacant E-03550 Spain

${ }^{2}$ Centro de Investigación Biomédica en Red sobre Enfermedades

Neurodegenerativas (CIBERNED), Barcelona, Spain

Full list of author information is available at the end of the article
}

leading to $\beta$-amyloid formation in the $\mathrm{AD}$ brain. The $\mathrm{A} \beta$ polypeptide is generated by processing of APP, through the successive action of two proteolytic enzymes, $\beta$-secretase and $\gamma$-secretase [2]. The major neuronal $\beta$-secretase has been identified as beta-site APP cleaving enzyme 1 (BACE1; [3]). As BACE1 contains a single transmembrane domain, its presence in CSF is not unexpected [4]. In contrast, $\gamma$-secretase consists of four essential subunits: presenilin-1 (or presenilin-2), nicastrin, APH-1 (anterior pharynx-defective 1), and PEN-2 (presenilin enhancer 2) [5]. Presenilin-1 (PS1), a transmembrane aspartyl protease, is the catalytic subunit, and has a nine-transmembrane domain topology [6]. A close homologue of PS1, presenilin-2 (PS2), shares a high degree of homology with the PS1 protein, has functional redundancy and also contains the active site of $\gamma$-secretase, forming similar but independent complexes [7].

\section{() Biomed Central}

(c) 2013 García-Ayllón et al.; licensee BioMed Central Ltd. This is an Open Access article distributed under the terms of the Creative Commons Attribution License (http://creativecommons.org/licenses/by/2.0), which permits unrestricted use, distribution, and reproduction in any medium, provided the original work is properly cited. 
To our knowledge, the presence of presenilins in CSF has not been reported to date. In this study we investigated if PS1 is detectable in CSF and if altered levels of this protein reflect the pathological condition.

\section{Results \\ PS1 NTF and CTF are present in high molecular mass complexes in CSF and plasma}

PS1 is known to undergo endoproteolytic cleavage as part of its maturation, generating $\mathrm{N}$ - and $\mathrm{C}$-terminal fragments (NTF and CTF) [8], with very little full-length PS1 detectable in brain or cultured cells [9]. To determine the presence of PS1 in human CSF, we first examined ventricular post-mortem CSF samples by Western blotting using different anti-PS1 NTF and CTF antibodies (a schematic representation of PS1 structure and epitopes for antibodies is represented in Figure 1A). Immunoblotting, using an antiPS1 NTF antibody (Calbiochem), revealed predominant bands of approximately 100 and $150 \mathrm{kDa}$ and only a faint 29-kDa band corresponding to PS1-NTF (Figure 1B). Immunoblotting with the PS1-CTF antibody 00/2 detected the 100-150-kDa complex, and a weak $\sim 20-\mathrm{kDa}$ band corresponding to PS1-CTF (Figure 1B). The use of alternative NTF and CTF antibodies confirmed the specificity of the PS1 signal in CSF samples (Figure 1B). Similar high molecular mass complexes of PS1, composed at least in part of both NTF and CTF, have been previously described in untransfected cells [10]. A similar banding pattern was obtained for PS2 complexes in CSF using the PS2-CTF antibody 00/12 (Figure 1C); PS2 fragments having similar high molecular mass as PS1 [7,11].

Difference in assay conditions, such as the presence of detergents, can affect the molecular interactions necessary for PS1 complex formation and its subsequent detection [10]. PS1 aggregates have previously been described as temperature-sensitive [12]. As the denaturation temperature prior to electrophoresis is not standardized, we determined the effect of sample heating during preparation on the stability of high molecular mass PS1 complexes. The high temperature used during sample preparation for electrophoresis $\left(98^{\circ} \mathrm{C}\right.$ compared with $50^{\circ} \mathrm{C}$ ), resulted in an overall loss of PS1 immunoreactivity, the higher molecular mass complexes being the most severely affected (Figure 1C). These experiments

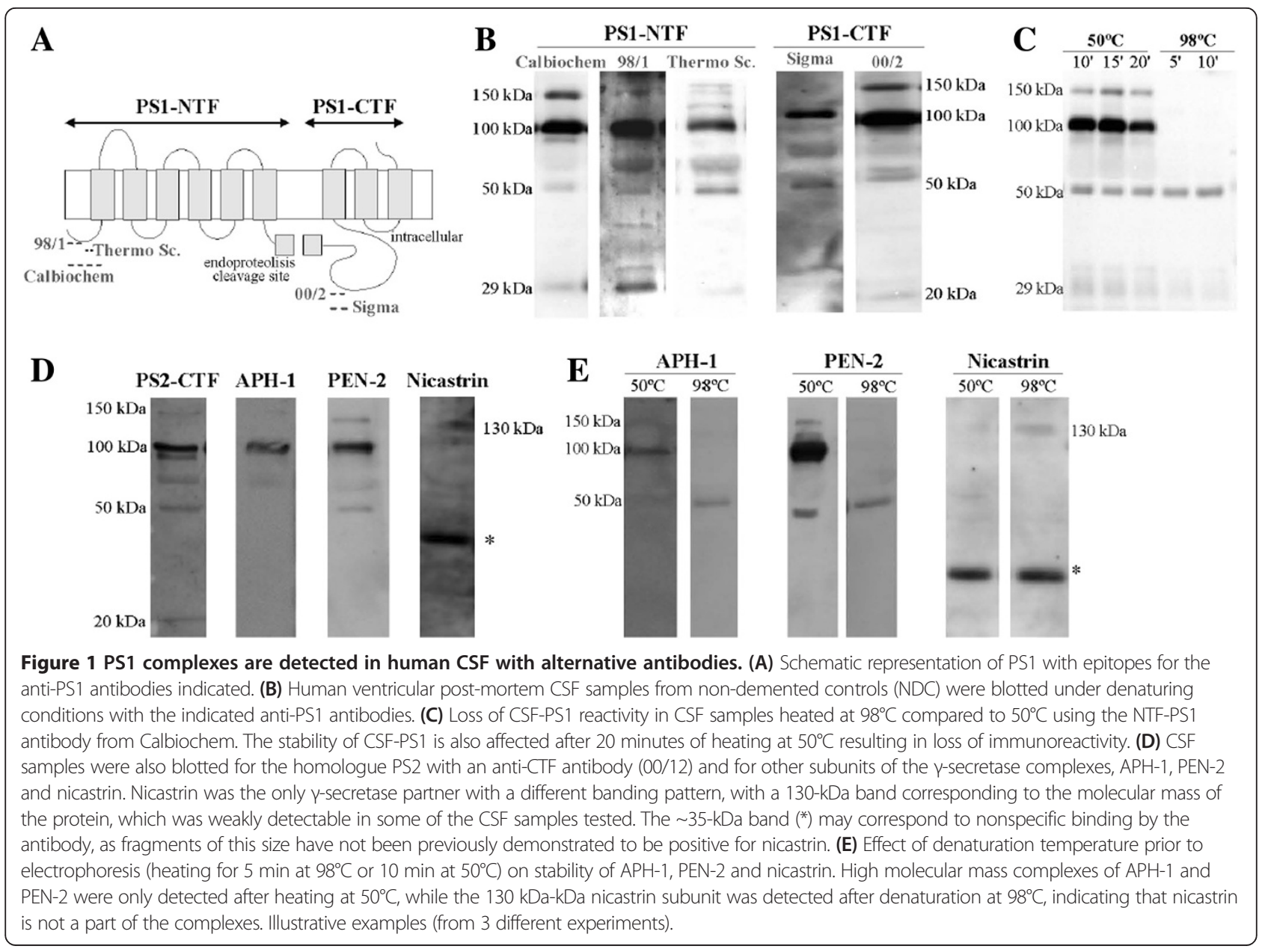


demonstrate that different assay methods and sample handling may influence the stability and detection of PS1 complexes. Studies performed with samples denatured at $98^{\circ} \mathrm{C}$ can therefore underestimate and fail to detect PS1 complexes. In this study, all analyses performed on PS1 avoided freeze-thaw cycles and denaturation before electrophoresis was conducted at $50^{\circ} \mathrm{C}$.

Interestingly, under the conditions used for PS1 complex detection, PEN-2 and APH-1 immunoreactivities in CSF displayed similar electrophoretic banding patterns. However the traces of nicastrin that were detected were not part of the high molecular mass presenilin complexes (Figure 1D). Nicastrin was only reliably detected when sample preparation for electrophoresis was performed at $98^{\circ} \mathrm{C}$ (Figure $\left.1 \mathrm{E}\right)$.
To further examine the identity of PS1complexes in human CSF, we performed immunoprecipitation/ Western blot analysis (Figure 2A). Post-mortem CSF samples were immunoprecipitated using the 98/1 antibody, an alternative PS1-NTF antibody which is effective in immunoprecipitating human PS1 [13]. Western blot analysis with the PS1-NTF antibody from Calbiochem and the PS1-CTF antibody 00/2 detected the predominant 100-150-kDa complexes. These bands were not observed in negative immunoprecipitation controls, including when an irrelevant rabbit IgG was used (Figure 2A). Considerable amounts of the $50-\mathrm{kDa}$ species were detected in PS1 immunoprecipitates using both anti-NTF and CTF antibodies. This species was also detected in NTF-PS1 immunoprecipitates from freshly collected ante-mortem lumbar

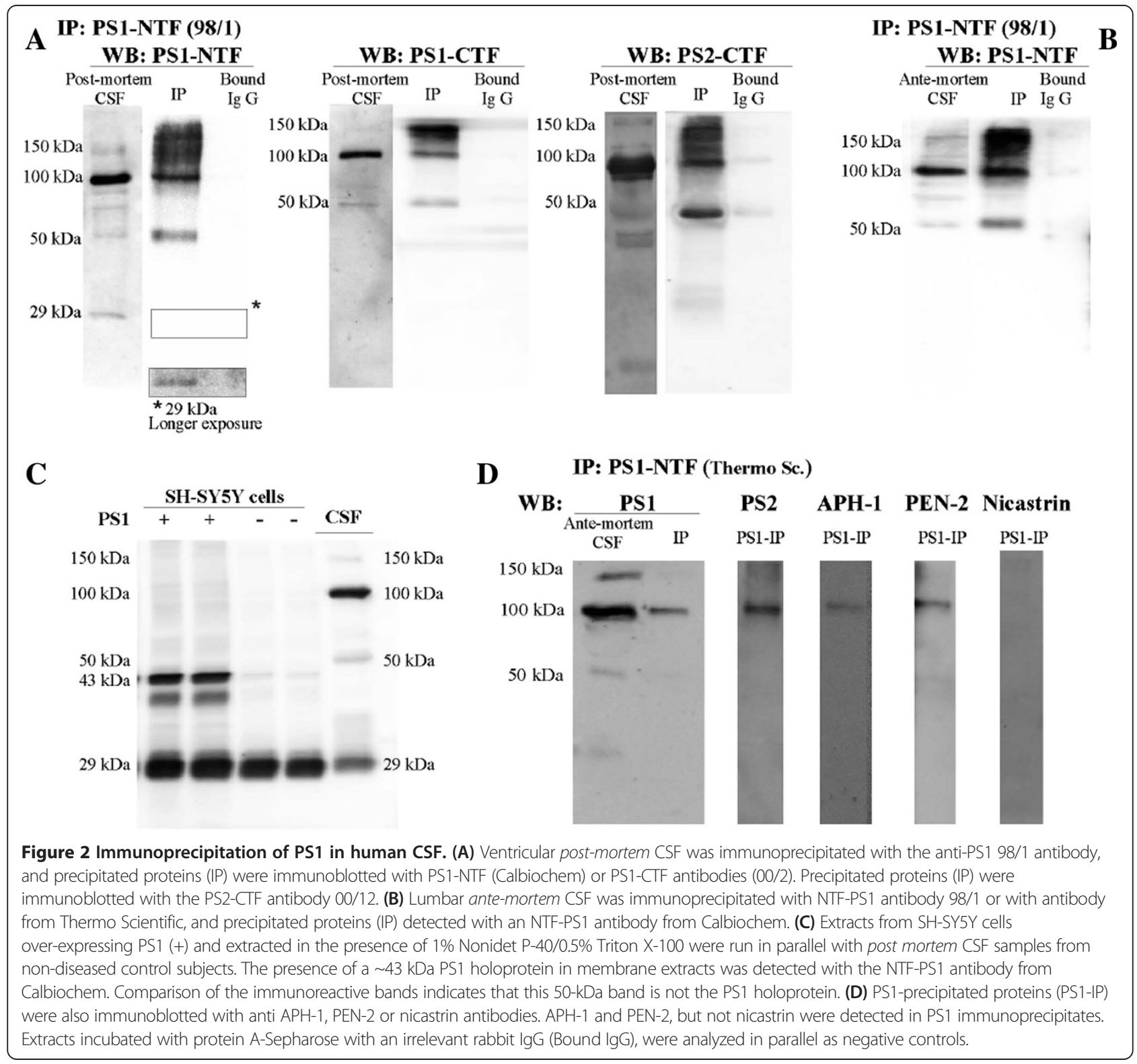


CSF samples (Figure 2B). These NTF/CTF-PS1 heterodimers probably arise from the 100 and $150 \mathrm{kDa}$ complexes during elution at acidic $\mathrm{pH}$, and are therefore not likely to be post-mortem artefact. The 50-kDa PS1 may also be derived from NTF and CTF-PS1 aggregation, as the holoprotein extracted from SH-SY5Y cells transfected with the human PS1 cDNA had a mass of $\sim 43 \mathrm{kDa}$ (Figure 2C).

The other known subunits of the $\gamma$-secretase complex, $\mathrm{APH}-1$ and PEN-2, were detected in freshly collected lumbar samples immunoprecipitated with an alternative PS1-NTF antibody, indicating that these components are part of the complexes (Figure 2D). These PS1 complexes from both post mortem and freshly collected lumbar CSF also contain PS2 fragments, demonstrating the existence of mixed complexes of PS1 and PS2 in the CSF (Figure 2A, 2D).

The CSF-PS1 complexes were further characterized and compared to human brain $\gamma$-secretase membrane complexes extracted in assay buffer containing 0.5\% dodecylmaltoside [14]. Both CSF and brain extracts were analyzed by blue native-PAGE (Figure 3A). As expected, in dodecylmaltoside-solubilized brain membrane fractions, all four $\gamma$-secretase subunits co-migrated in several bands. A weak band immunoreactive for PS1 was identified at $\sim 250 \mathrm{kDa}$ (open arrowhead). This molecular mass corresponds to the smallest sized complex in which active $\gamma$-secretase has been observed [15]. However, this band was not immunoreactive for all the other $\gamma$-secretase subunits. A predominant immunoreactive band, with a molecular mass of $\sim 450 \mathrm{kDa}$ (closed arrowhead), was detected with all antibodies. Other high molecular mass bands, corresponding to large $\gamma$-secretase complexes $[15,16]$, were also immunoreactive for the different $\gamma$-secretase subunits, PS1, APH-1 and PEN-2. By blue native-PAGE, PS1-CSF complexes appeared as a smear from $\sim 200$ to $1000 \mathrm{kDa}$ (Figure 3A). In agreement with results obtained from SDS-PAGE analysis; only APH-1 and PEN-2 were present in these CSF-PS1 complexes (Figure 3A). The interpretation of results from blue native-PAGE analysis of membrane protein complexes is tricky, especially for the limitations of these methods of size determination by comparison with the mobilities of hydrophilic molecular mass markers.

Previous studies have also utilized gradient centrifugation to characterize PS1 complexes [10]. PS1 complexes were further characterized in lumbar CSF samples and dodecylmaltoside-solubilized brain membrane fractions by fractionation on sucrose density gradients containing the detergent Brij 97 (Figure 3B).

The majority of the PS1 solubilized from human brain in presence of dodecylmaltoside accumulated close to the alkaline phosphatase marker (molecular mass $~ 140$ $160 \mathrm{kDa})$, and were resolved as a $29-\mathrm{kDa}$ band by
Western blotting using an NTF-PS1 antibody under denaturing conditions. Brain-PS1 complexes were also identified in denser fractions, close to the sedimentation rate of catalase (molecular mass $\sim 232 \mathrm{kDa}$ ). Interestingly, these large PS1 complexes were resolved as $\sim 50$ kDa heterodimers. However, CSF-PS1 complexes which sediment close to alkaline phosphatase were resolved as stable $100-150 \mathrm{kDa}$ complexes, instead of monomeric NTF-PS1 (Figure 3B). Large CSF-PS1 complexes were also resolved as $\sim 50-\mathrm{kDa}$ heterodimers, indicating that these complexes are less stable in the CSF than those which sediment at $100-150 \mathrm{kDa}$. APH-1 and PEN-2 were again identified as components of the CSF-PS1 complexes (Figure 3C).

No measurable $\gamma$-secretase activity [17] was detected in freshly collected lumbar CSF samples from nondemented subjects $(n=5)$. These results indicate that CSF-PS1 complexes differ from the active $\gamma$-secretase complexes found in the brain, and may represent nonspecific aggregation of PS1 fragments (together with APH-1 and PEN-2, but not nicastrin) in the CSF.

Soluble PS1 complexes were also detected in human plasma (Figure 4A), and in mouse CSF and plasma (Figure 4B). PS1 complexes were mostly absent in CSF from a PS1 cKO mouse model where PS1 expression has been selectively eliminated in neurons from the postnatal forebrain, decreasing brain PS1 levels [18]. However, PS1 complexes were present in serum samples from these PS1 cKO mice, indicating that CSF and plasma PS1 complexes have distinct cellular origins.

\section{PS1 levels are increased in AD ventricular post-mortem CSF}

To assess whether PS1 levels are altered in AD, we analyzed ventricular post-mortem CSF for NTF and CTF-PS1 in $10 \mathrm{AD}$ and in $7 \mathrm{NDC}$ samples. The 100 and $150-\mathrm{kDa}$ complexes were detected with an anti-NTF antibody in all CSF analyzed (Figure 5A). The immunoreactivity for the $100+150 \mathrm{kDa}$ complexes increased by $\sim 325 \%$ in AD compared to NDC subjects $(p=0.005)$. New aliquots of the same CSF samples were immunoblotted with an antiCTF-PS1 antibody (Figure 5B). In good agreement, CTFPS1 immunoreactivity for the $100+150 \mathrm{kDa}$ complexes increased by $\sim 320 \%$ in AD compared to NDC subjects $(p=0.002)$. The minor form of PS1 $(29-\mathrm{kDa})$ was decreased in AD compared to NDC subjects ( $70 \%$; $p=0.03$ ); while the $20 \mathrm{kDa}$-band corresponding to monomeric PS1-CTF was only very weakly detected and not quantified.

Fractionation on sucrose density gradients followed by Western blotting under denaturing conditions revealed that the highly stable $100-150 \mathrm{kDa}$ complexes were more abundant in AD samples, while less stable complexes that sediment in denser fractions were mostly detected in NDC samples. This difference enabled us to define a quotient 


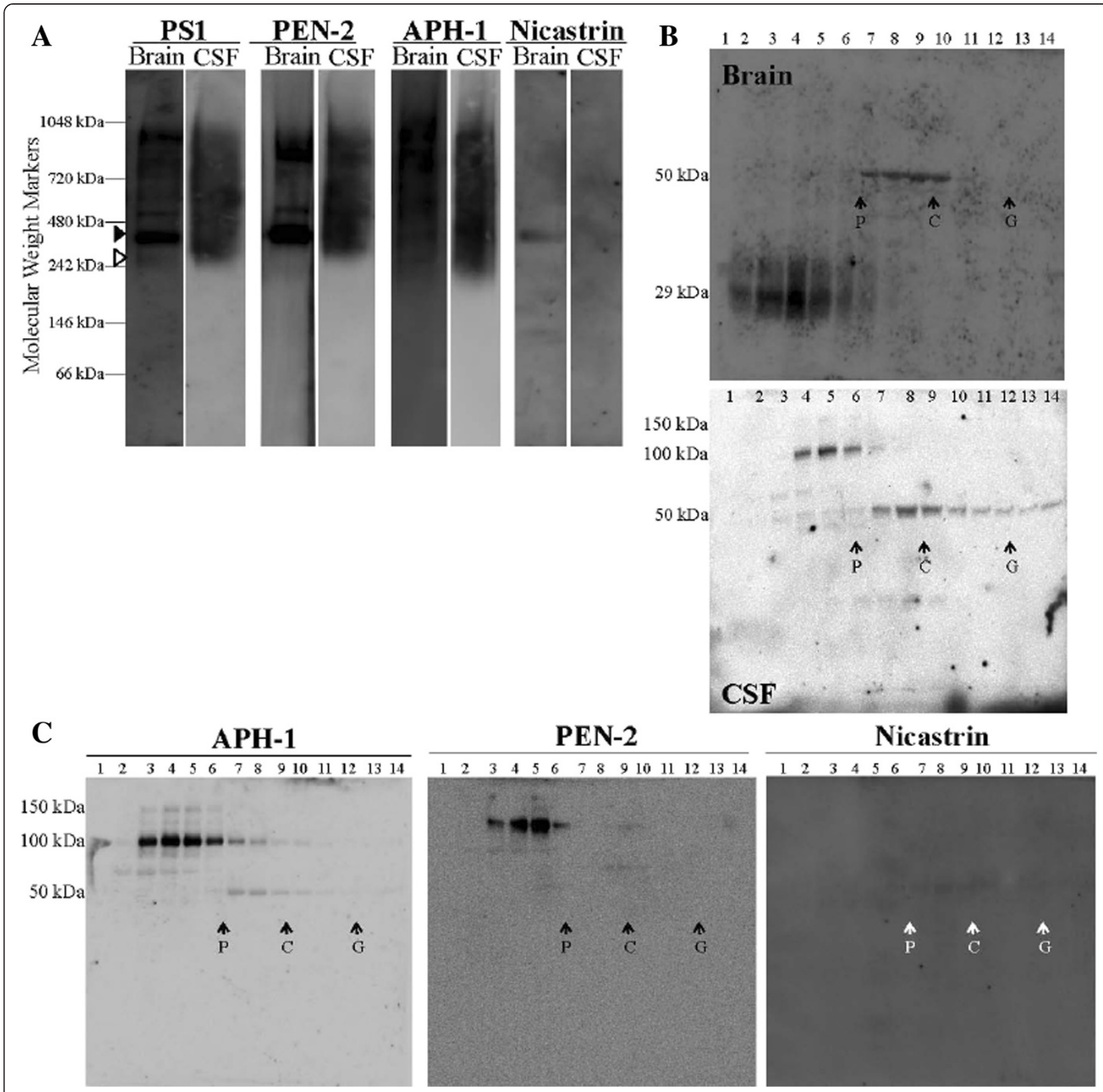

Figure 3 Characterization of CSF-PS1 complexes. (A) Brain $y$-secretase complexes (frontal cortex from non-diseased control subjects extracted in buffer containing $0.5 \%$ dodecylmaltoside) were analyzed by blue native-PAGE and compared with PS1 complexes isolated from lumbar CSF samples (NDC cases). Incubation of blots with antibodies for the different $\gamma$-secretase subunits confirmed that nicastrin is not present in CSF-PS1 complexes. (B) The same brain extract and CSF samples were also fractionated on 5-20\% sucrose density gradients. The fractions (collected from the top of each tube) were immunoblotted for NTF-PS1 under denaturing conditions with the antibody from Calbiochem. Enzymes of known sedimentation coefficient, $\beta$-galactosidase $(\mathrm{G}, 16.0 \mathrm{~S} ; \sim 540 \mathrm{kDa})$, catalase $(\mathrm{C}, 11.4 \mathrm{~S} ; \sim 232 \mathrm{kDa})$ and alkaline phosphatase $(\mathrm{P}, 6.1 \mathrm{~S} ; \sim 140-160 \mathrm{kDa})$ were used as internal markers. (C) CSF fractions from sucrose gradients were also blotted for APH-1, PEN-2 and nicastrin. Nicastrin was mostly undetectable in fractionated CSF samples.

between highly stable complexes (represented by 100-150$\mathrm{kDa}$ heterodimers which sediment closer to alkaline phosphatase) and unstable complexes (50-kDa complexes which sediment closer to catalase), allowing us to fully discriminate between the two groups (Figure 5C).
Highly stable PS1 complexes are increased in AD lumbar ante-mortem CSF

We have demonstrated that high molecular mass PS1 complexes are increased in post-mortem AD CSF. These PS1 complexes were also assessed in lumbar CSF 


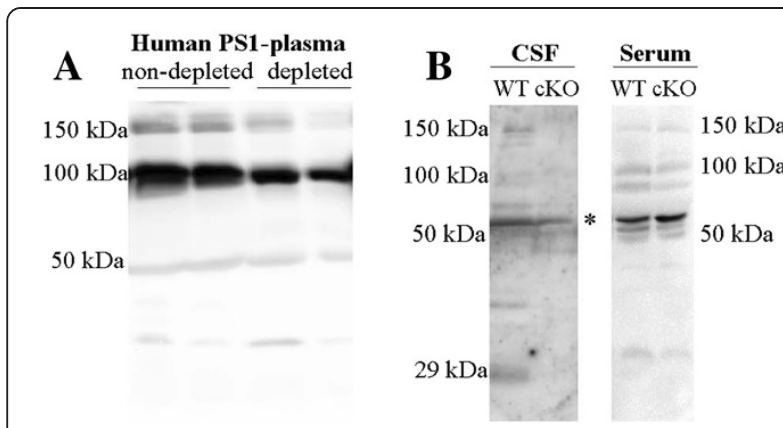

Figure 4 PS1 complexes are present in human and mouse CSF and plasma. (A) Plasma samples from NDC subjects were blotted with an anti-NTF-PS1 antibody (from Calbiochem) with and without depletion of plasma abundant proteins by immunoaffinity-based protein subtraction chromatography with IgY microbeads (Seppro ${ }^{\mathrm{TM}}$ ). (B) CSF and plasma samples from control wild-type (WT) and PS1 conditional knockout mice (CKO) were blotted with an anti-NTF-PS1 antibody. In general, immunoreactivities of the bands corresponding to PS1 complexes were weak in mouse (or rat, not shown) than in human samples. PS1 levels are reduced in CSF from PS1 CKO mice, and unchanged in plasma. PS1 immunoreactivity detected in CSF from PS1 CKO mice may be due to PS1 expressed in glia and interneurons. However, it is also highly likely that some nonspecific binding may occur at $50 \mathrm{kDa}\left(^{*}\right)$.

from probable AD and control subjects. Measurement of classical AD biomarkers displayed elevated CSF Ttau and P-tau and low levels of A $\beta 42$ in probable AD samples (Figure 6). As expected, predominant PS1 bands of approximately 100 and $150 \mathrm{kDa}$ were detected in all cases, although no notable changes were observed in total PS1 levels between probable AD and NDC subjects (Figure 7A). No detectable amount of the 29-kDa species was evident in lumbar CSF samples, nor in immunoprecipitates from lumbar CSF samples (see Figure 2). Sucrose density centrifugation profiles (determined in 8 of the 12 lumbar CSF cases, for both the AD and NDC groups, due to limited volumes) revealed a major contribution of the highly stable PS1 complexes in probable AD cases, compared to NDCs (Figure 7B). Interestingly, the quotient of the PS1 complexes fractionated in the sucrose gradient correlates with A $342(\mathrm{r}=0.51, p=0.04)$ and with P-tau levels $(\mathrm{r}=0.57, p=0.02)$. In the NDC group, age trends to positive correlates with the quotient of the PS1 complexes $(\mathrm{n}=8 ; \mathrm{r}=0.70, p=0.07)$.

\section{Levels of full-length BACE1 in CSF}

BACE1, the major neuronal $\beta$-secretase, together with $\gamma$ secretase, processes APP through the amyloidogenic pathway [2]. BACE1 activity levels have been found to increase in AD CSF and it has been identified as a potential diagnostic marker for AD [4,19-21]. It's has been assumed that the BACE1 present in CSF is a truncated soluble form of the originally membrane-bound BACE1, missing the transmembrane and intracellular domains [22]. However, it's possible to identify BACE1 in CSF by Western blotting using an anti-BACE1 antibody which binds the C-terminal intracellular domain (antibody D10E5 from Cell Signaling, with antigenic determinant located in residues surrounding $\mathrm{Asp}^{490}$ of human BACE1 protein). Using this antibody, we have evaluated BACE1 levels by Western blotting in the same set of post-mortem CSFs. Full-length BACE1 was significantly elevated in AD patients compared with controls ( $p=0.018$; Figure 8A). Full-length BACE1 levels also correlated with PS1 when the quotient of the PS1 complexes fractionated on sucrose gradients are considered for all samples $(\mathrm{r}=0.95$, $p<0.001)$, or for AD cases $(\mathrm{r}=0.93, p<0.001)$. No change was observed in full-length BACE1 levels evaluated in lumbar CSF from probable AD and control subjects (Figure 8B).

\section{Discussion}

To our knowledge, the possibility that PS1 can be assessed in the CSF has thus far not been considered. Here, we demonstrate that heterodimeric complexes composed of NTF and CTF PS1 are detectable in CSF. To date, the presence of soluble CTF-PS1 has only been demonstrated in culture medium of primary neurons and HEK cells [23].

The majority of mature brain PS1 protein is present as proteolytic NTF- and CTF-PS1 fragments [8]. The existence of 100-150-kDa complexes containing both endogenous NTF and CTF-PS1 has only previously been described in cultured cells [10]. PS1 exhibiting higher molecular mass bands in SDS-PAGE, has also been described in cellular models over-expressing the protein [24,25]. These high molecular mass bands of PS1 were detected by alternative anti-NTF and CTF-PS1 antibodies, confirming that heterodimers contain both PS1 fragments. Triton X-100, a common detergent frequently used to extract and solubilise membrane bound proteins, disassembles the 100-150$\mathrm{kDa}$ complexes [10], and these PS1 heterodimeric species have therefore been mischaracterized in the many previous studies. The sensitivity of these complexes to high temperatures during sample preparation may contribute to its mischaracterization. The presence of the minor $29-\mathrm{kDa}$ NTF and 20-kDa CTF species was only clearly detectable in post-mortem CSF, where artefacts are likely to appear. Similarly, the $50-\mathrm{kDa}$ species was only resolved as a major PS1 band in immunoprecipitates after elution at acid pH.

Ultracentrifugation in sucrose density gradients containing the detergent Brij 97 confirms the existence of stable complexes of $100-150-\mathrm{kDa}$, and also of large complexes which sediment in regions closer to 200 and $250 \mathrm{kDa}$. These large complexes are unstable and resolve as $50-\mathrm{kDa}$ components during electrophoresis under denaturing conditions. 

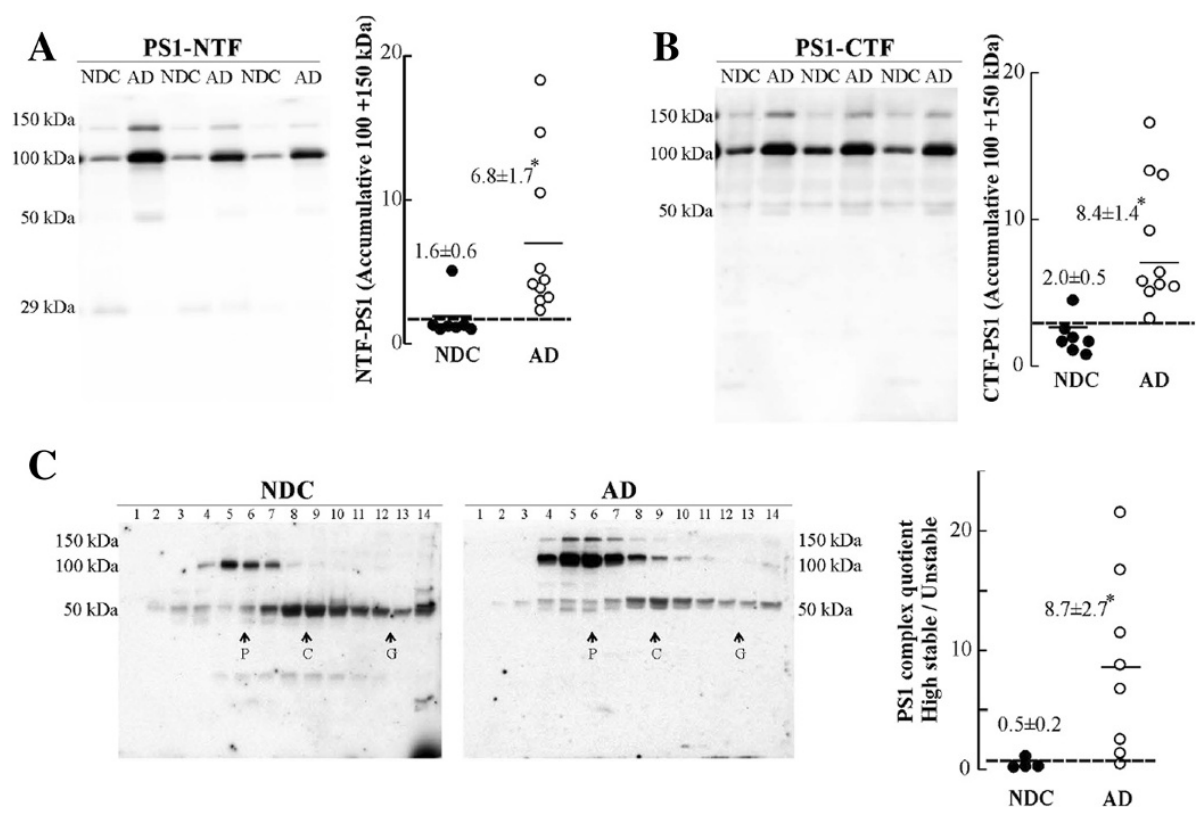

Figure 5 PS1 stable complexes are increased in AD post-mortem CSF. (A) Representative blot of NTF-PS1 in post-mortem CSF samples from $10 \mathrm{AD}$ (open circles) and $7 \mathrm{NDC}$ controls (closed circles). The densitometric quantification of the accumulative immunoreactivity from the sum of the higher molecular mass PS1 complex (100 + $150 \mathrm{kDa}$ ) is shown. (B) Immunodetection and densitometric quantification of higher molecular mass PS1 complex $(100+150 \mathrm{kDa})$ from CSF samples blotted with an anti-CTF-PS1 antibody. Dashed lines represent arbitrary cutoffs that maximally discriminated between AD and NDC groups. (C) PS1 complexes in 4 (of 7) NDC (closed circles) and 8 (of 10) AD CSF samples (open circles) were fractionated on 5-20\% sucrose density gradients. The fractions (collected from the top of each tube) were immunoblotted for NTF-PS1 under denaturing conditions with the antibody from Calbiochem. Enzymes of known sedimentation coefficient, $\beta$-galactosidase (G, 16.0S; $540 \mathrm{kDa})$, catalase (C, 11.4S; 232 kDa) and alkaline phosphatase ( $\mathrm{P}, 6.1 \mathrm{~S} ; \sim 140-160 \mathrm{kDa}$ ) were used as internal markers. Representative blots are shown. A quotient between highly stable complexes $(100+150 \mathrm{kDa}$ immunoreactive bands sediment closer to alkaline phosphatase, fractions 2-7) and unstable complexes (50-kDa immunoreactive bands sediment closer to catalase, fractions 8-12) was defined and represented. Dashed lines represent an arbitrary cutoff that maximally discriminated between $A D$ and NDC groups. The data represent the means (in arbitrary units) \pm SEM. *Significantly different $(p<0.05)$ from the NDC group, as assessed by the Mann-Whitney U test.

$\gamma$-Secretase exists on the plasma membrane as an intact complex composed of its subunit components $[15,26]$, at a stoichiometry of presenilin:PEN-2:nicastrin: APH-1, 1:1:1:1 [27]. However, PS1 can associate intramolecularly to form higher order complexes [28], where nicastrin, APH-1 and PEN-2 do not seem to be required for its hetero- and homodimerization [29]. Interestingly, our studies have identified APH-1 and PEN-2, but not nicastrin in the PS1-complexes. $\gamma$-Secretase activity depends on the presence of all four components of the complex, including nicastrin [30,31]. As we were unable to detect $\gamma$-secretase activity in human CSF, PS1 complexes in CSF are therefore likely to be the result of nonspecific aggregation of the protein. PS1-CSF complexes appeared as a smear (from $\sim 200$ to $1000 \mathrm{kDa}$ ) and not as defined complexes on blue native-PAGE. PS2

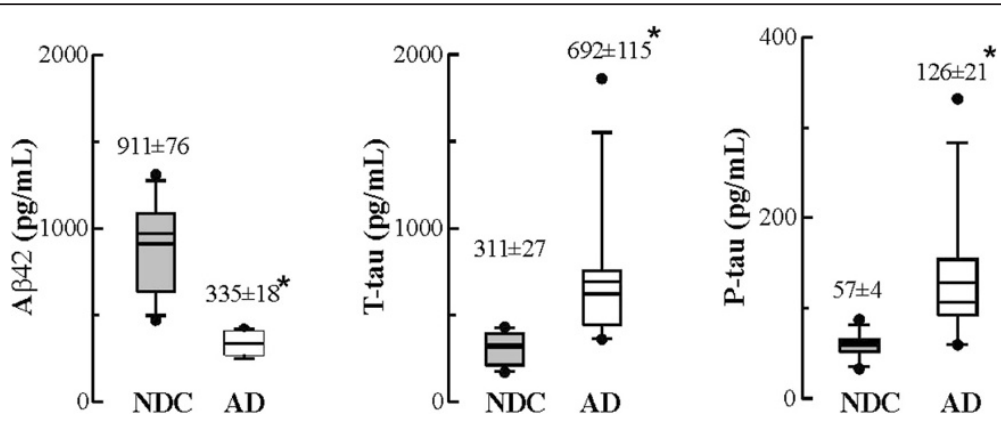

Figure 6 Levels of classical AD biomarkers in lumbar CSF. Box plot of CSF levels of A 42 , T-tau and P-tau for the 12 probable AD cases (open circles) and the 12 NDC controls (closed circles). Means \pm SEM are shown. Mann-Whitney $U$ test, ${ }^{*} p<0.05,{ }^{* *} p<0.01$. 


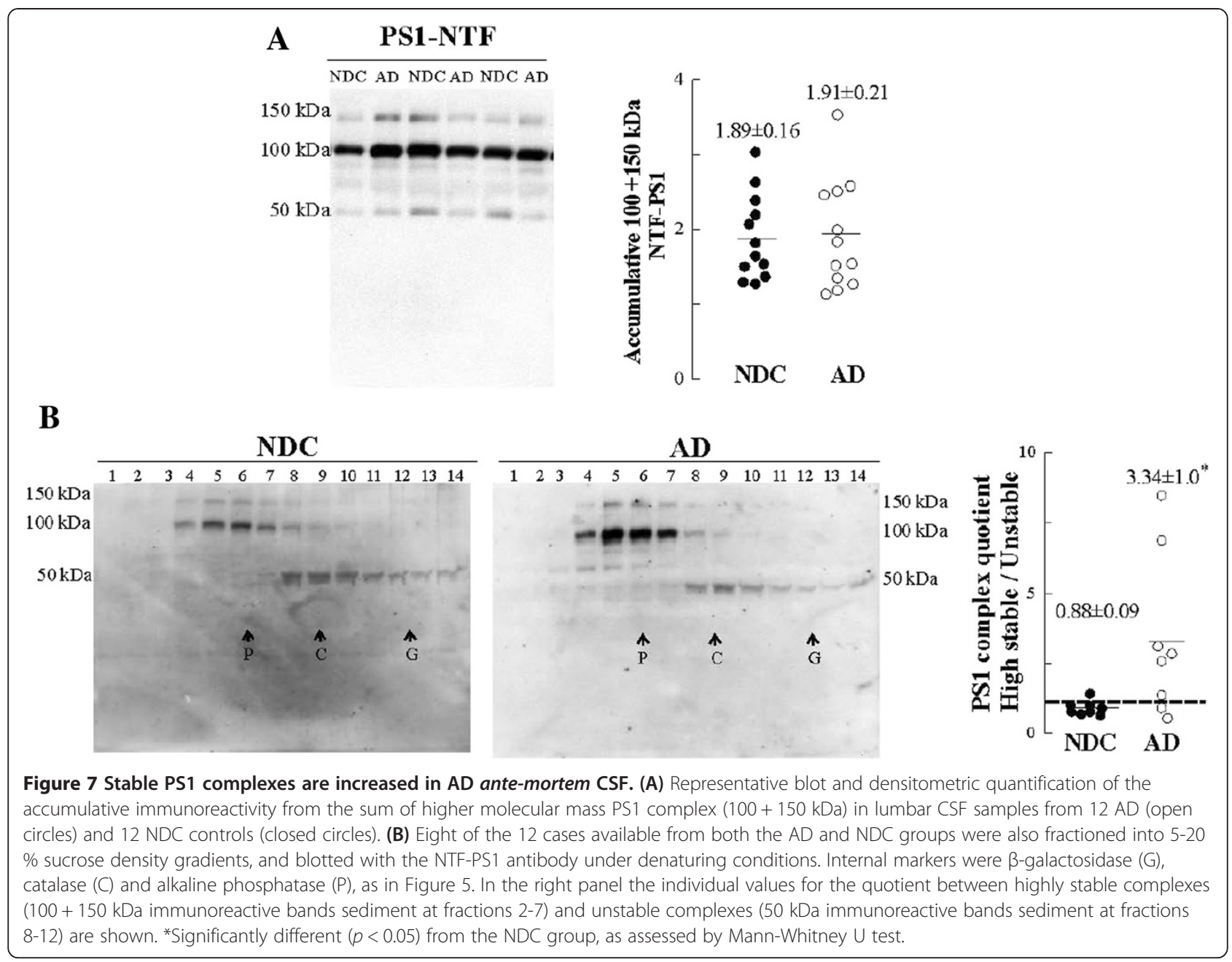

has been shown to form similar but independent $\gamma$ secretase complexes in cell membranes, and PS2 does not co-precipitate with PS1 fragments in membrane extracts $[7,32]$. We were able to demonstrate that fragments of PS2 are bound to the same PS1 complexes in CSF. As presenilins are proteins with large numbers of hydrophobic regions, presenilin fragments may be highly unstable in CSF, and spontaneously form complexes. Indeed, like many membrane proteins, PS1 has exhibited a tendency to aggregate under non-native conditions $[11,12]$. Thus, in normal conditions, the amount of free CTF and NTF in CSF should be very low as PS1 predominantly exists as complexes. Preliminary analysis indicates that PS1 complexes do not contain some of the abundant CSF proteins known to bind hydrophobic proteins (e.g., albumin). Further characterization of these complexes is yet to be conducted. The possibility that other proteins, such as A $\beta$, may also be part of the PS1 complex needs to be addressed. Similarly, the source and mechanism of how PS1 appears in CSF is yet to be determined. Active secretion is unlikely, and it is still unclear if passive release from brain cells or neuronal death may be major contributing factors, as recently observed for BACE1 [33].

Stable 100-150-kDa complexes are more abundant in AD CSF, and this may reflect differences in the hydrophobic and ionic properties of PS1 complexes formed under amyloidogenic conditions. In this context, it is also remarkable that the $29-\mathrm{kDa}$ NTF, detectable only in post-mortem CSF, is less abundant in AD samples, indicating that complexes formed under amyloidogenic conditions are particularly stable. Whether PS1 complexes differ between $\mathrm{AD}$ and non-demented subjects requires further research.

It is likely that molecular aberrations in the AD brain are reflected in the CSF. Although it cannot be excluded that the accumulation of $A \beta$ in $A D$ may be partly due to deficient clearance of the peptide, an increase in the generation of $A \beta$ is plausible. Thus, an increase in activity and/or levels of $\beta$ - and $\gamma$-secretase protein components should be expected. These catalytic effectors of $\beta$ - and $\gamma$-secretase are key enzymes in pathological amyloid processing and the 


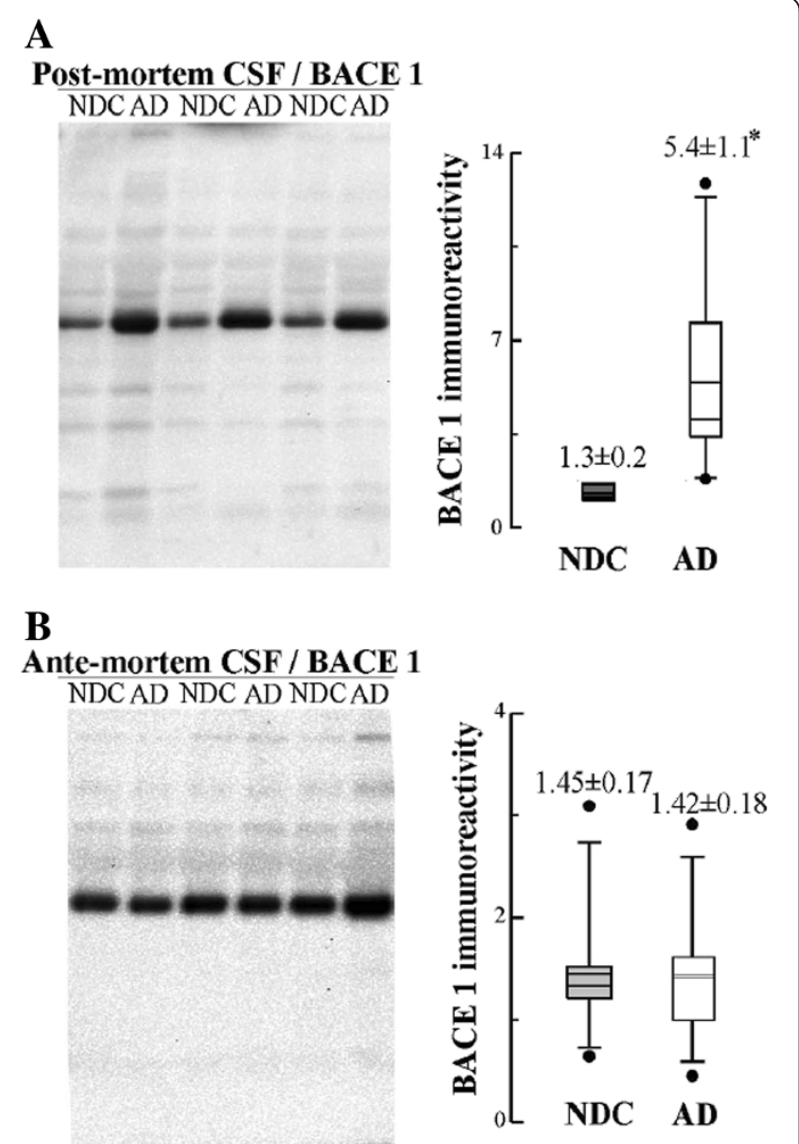

Figure 8 BACE1 levels in the post-mortem and ante-mortem CSF samples. (A) Immunodetection and densitometric quantification of the 70-kDa immunoreactive BACE1 band from the same post-mortem CSF cases, AD (open circles) and NDC (closed circles), presented in Figure 5; and (B) from the same ante-mortem CSF cases, AD (open circles) and NDC (closed circles), presented in Figure 6. The box blot of BACE1 levels includes the means of the immunoreactivities (in arbitrary units) \pm SEM (determinations by duplicate). ${ }^{*} p<0.05$ significantly different from NDC group, as assessed by the Student's t test.

subsequent generation of $\mathrm{A} \beta$ constitutes a central event in AD progression. However, it is still unclear if $\gamma$-secretase activity is altered. Reported levels of PS1 in AD brains have been contradictory. Reports have displayed an increase $[34,35]$, unchanged levels [36] or even a decrease [37,38] in levels, compared to levels in non-demented brains. At the transcriptional level, early reports indicate no differences between PS1 mRNA levels in AD brain compared to controls [39]. However subsequent research suggests that PS1 mRNA levels in human AD brains are significantly higher than in those with no dementia [34,40]. Interestingly, we have shown that $A \beta$ peptide treatment of cultured cells is able to induce increases in cellular PS1 levels [41], probably as part of a vicious cycle of $A \beta$ generation.

In our analysis, ventricular post-mortem samples display large differences in the level of PS1 and the stability of its complexes. Lumbar CSF samples only display differences in PS1 complex stability as resolved by sucrose density gradients. Thus, despite high levels of PS1 correlating with an increased proportion of stable complexes in post-mortem CSF, results in lumbar CSF suggest that the early and more significant phenomenon is the change in the dynamics of the assembly of PS1 complexes, a change that appears to be a better marker for discriminating between pathological samples than total PS1 protein levels alone. In any case, the comparison between the two different sets of CSF samples is difficult, as the potential existence of artefacts in the post-mortem samples and the possibility that ventricular and lumbar CSF samples may differently reflect brain protein content. Moreover, our collection of lumbar CSF samples display clear differences for classical AD biomarkers, but the inherent uncertainty in clinical diagnosis should indeed be considered. Although, the more obvious difference between the CSF collections is that post-mortem CSF reflects late stages of the disease, whereas lumbar CSF corresponds to earlier stages of disease in patients. Nonetheless, CSF PS1, combined with other biomarkers, may constitute a potential new marker for AD. Furthermore, CSF PS1 may have value as a marker of disease progression or for monitoring treatment.

As there is still a lack of reliable blood biomarkers for neurodegenerative disorders, it is important to assess if levels in plasma of new potential biomarkers correlate with AD. PS1 is expressed in many peripheral organs as well as the brain $[42,43]$. The presence of PS1 complexes in the serum of PS1 cKO mice, in which PS1 is specifically absent in neurons of the forebrain, while mostly absent in CSF, suggests that plasma and CSF PS1 may have distinct cellular origins. Although a small contribution of brain PS1 to plasma levels cannot be discounted, our results indicate that PS1 detection in plasma will not be an efficient marker for brain disorders.

\section{Conclusion}

In conclusion, accurate diagnosis of $\mathrm{AD}$ during life is essential. Numerous laboratories have reported an increase in levels of T-tau and P-tau in CSF, but tau is also increased as result of other neurological processes. While levels of the pathological A $\beta 42$ species are also increased in the AD brain, the levels in CSF are decreased due to increasing deposition [44]. These biomarkers have shown diagnostic accuracy for incipient AD [45], however, there is still a need to identify additional specific biochemical markers of AD. Proteins involved in the pathological processing of amyloid are potential candidates. In this study we demonstrate that CSF PS1 has potential as a new biomarker. The diagnostic value of CSF PS1 in the early stages of AD and in other dementias requires further study. In addition, biomarkers are also important to evaluate drug effects underlying pathophysiology of the disease [44]. One of the promising AD 
drugs under development are $\gamma$-secretase inhibitors $[46,47]$. Estimation of PS1 CSF levels may therefore be useful to challenge the disease-modifying effects of newer Alzheimer's therapy.

\section{Methods \\ Patients, PS1 conditional knockout mice and PS1 over-expressing cells \\ Post-mortem material}

Ventricular CSF was obtained post-mortem at the Banco de Tejidos, Fundación CIEN (Madrid, Spain), Fundación Hospital de Alcorcón (Madrid, Spain) and Fundación AlzheimUr (Murcia, Spain). Samples contaminated with blood were excluded from analysis. CSF was centrifuged at $1000 \times \mathrm{g}$ for $15 \mathrm{~min}$ to eliminate cells and insoluble material prior to biochemical analyses. AD cases $[n=10$ ( $5 \mathrm{fe}-$ male and 5 male); mean age \pm standard error of mean (SEM); $77 \pm 2$ years] were selected based on clinical history of dementia and neuropathological CERAD diagnosis [48]. Samples from age-matched non-demented control (NDC) cases had no clinical or pathological features of dementia [n = 7 ( 2 female and 5 male); $72 \pm 3$ years]. Only samples with a post-mortem interval lower than $14 \mathrm{hr}$ were included, with no differences between groups.

Microsomal membranes were solubilized from $0.2 \mathrm{~g}$ of human frontal cortex (two NDC cases from Banco de Tejidos, Fundación CIEN) in buffer containing 0.5\% dodecylmaltoside, $20 \%$ glycerol, and $25 \mathrm{mM}$ Bis-Tris $/ \mathrm{HCl}$, $\mathrm{pH}$ 7.0, as previously described [14]. $\gamma$-Secretase complexes extracted from membrane preparations were analyzed by blue native-PAGE.

\section{Clinical material}

Lumbar CSF samples were obtained from 12 patients ( 5 men and 7 women, $71 \pm 5$ years) with mild-moderate $\mathrm{AD}$, and 12 healthy volunteers (5 men and 7 women, $66 \pm$ 9 years) from Huddinge University Hospital (Stockholm, Sweden). All AD patients fulfilled the NINCDS-ADRDA criteria for "probable" AD [49]. Controls had no history or symptoms of neurological or psychiatric disorders, or memory complaints, and had an MMSE score of 28 or higher. Five non-demented control CSF samples (2 men and 3 women, $52 \pm 7$ years) obtained from the Hospital General Universitario de Elche (Elche, Spain) were analytically processed within 24-48 hours of collection to avoid freezing and thawing of the samples.

Plasma samples from five healthy volunteers (76 \pm 1 years) were collected in heparinized tubes at the Hospital General Universitario de Elche and separated from whole blood by centrifugation at $3000 \times \mathrm{g}$ for $15 \mathrm{~min}$ at $4^{\circ} \mathrm{C}$. CSF and plasma samples were aliquoted and frozen at $-80^{\circ} \mathrm{C}$ until use.

\section{Material collected from animals}

CSF and plasma samples were also collected from four 3 month-old PS1conditional knockout mice (PS1 cKO) and five littermates in a C57BL6/129 hybrid background. In these cKO mice, PS1 expression has been selectively eliminated in glutamatergic neurons from the postnatal forebrain at P18, and at 2-3 months of age revealed no detectable brain PS1 [50]. CSF (4-6 $\mu \mathrm{L})$ was obtained by cisternal puncture with a needle inserted in the suboccipital region through the atlanto-occipital membrane, with a single incision of the subarachnoid space as previously described [51]. Blood was withdrawn $(0.2 \mathrm{~mL})$ by cardiac puncture with heparinized needles and syringes. CSF and plasma samples were centrifuged at $1000 \times \mathrm{g}$ for $10 \mathrm{~min}$ at $4^{\circ} \mathrm{C}$ and the supernatants stored at $-80^{\circ} \mathrm{C}$ until further analysis.

\section{Material collected from cells}

SH-SY5Y cells $(800,000$ cells/well) were grown in 6 well plates and transfected with a construct encoding fulllength PS1 [52] (or with the expression plasmid pcDNA3 (Invitrogen), using Lipofectamine $2000^{\circ}$ (Invitrogen) according to the manufacturer's instructions.

\section{Western blotting and immunoprecipitation}

CSF samples (30-40 $\mu \mathrm{L}$ from human subjects; pooled volume of $15 \mu \mathrm{L}$ from 3 mice), or plasma samples $(0.5 \mu \mathrm{L})$ were denatured at $50^{\circ} \mathrm{C}$ for $15 \mathrm{~min}$ or alternatively at $98^{\circ} \mathrm{C}$ for $5 \mathrm{~min}$ for other analyses. For BACE1 analysis CSF samples were denatured always at $98^{\circ} \mathrm{C}$ for $5 \mathrm{~min}$. Samples were resolved by sodium dodecyl sulfate-polyacrylamide gel electrophoresis (SDS-PAGE) under fully reducing conditions. For blue-native gel electrophoresis, samples were analyzed as previously described [53] and NativeMark ${ }^{\text {тM }}$ Unstained Protein Standards (Life Techologies) were used for molecular weight markers. Alternatively, human plasma samples were first depleted of highly abundant proteins using immunoaffinity-based chromatography (Seppro ${ }^{\circ}$ IgY14 spin column kit, GenWay Biotech Inc) prior to gel electrophoresis $(25 \mu \mathrm{g}$ of protein after protein depletion). The separated proteins were transferred to nitrocellulose membranes (Schleicher and Schuell Bioscience GmbH) and probed with PS1 antibodies to N-terminal amino acids 1-65 (Calbiochem), amino acids 21-34 (from Thermo Scientific), amino acids 1-20 (antibody 98/1, [54]); amino acids 303-316 in the loop region of the C-terminal (Sigma), or to amino acids 301-317 in the loop region of human PS1 (antibody 00/2; [54]). CSF proteins were also probed for PS2 using the polyclonal rabbit antibody "00/12," raised to residues 307-336 of the human PS2 loop domain [55]. BACE1 antibody was from Cell Signaling, nicastrin antibody was from Millipore, APH-1, PEN-2 and albumin antibodies were from Sigma. Individual blots were used for the different antibodies, to eliminate antibody cross-reactivity. 
Blots were incubated with the corresponding secondary antibody conjugated to horseradish peroxidase and the signal was detected using ECL Plus detection reagent according to the manufacturer's instructions (GE Healthcare) in a Luminescent Image Analyzer LAS1000 Plus (FUJIFILM). A control CSF sample was used to normalize the immunoreactive signal. For semiquantitative studies, the intensity of immunoreactive bands was measured by densitometry using Science Lab Image Gauge v 4.0 software provided by FUJIFILM.

Immunoprecipitations were performed at $4{ }^{\circ} \mathrm{C}$ by incubating $150 \mu \mathrm{L}$ of CSF overnight with the primary $\mathrm{N}$ terminal PS1 antibody $98 / 1$, or alternatively with an antibody from Thermo Scientific, previously coupled to protein A-Sepharose by Dimethyl pimelimidate dihydrochloride (Sigma-Aldrich Co). Precipitated proteins were washed with PBS and eluted with $0.1 \mathrm{M}$ glycine buffer at $\mathrm{pH}$ 2.5. After $\mathrm{pH}$ neutralization, supernatants were denatured in Laemmli sample buffer at $50^{\circ} \mathrm{C}$ for $15 \mathrm{~min}$ and subjected to SDS-PAGE, and separated proteins were transferred to nitrocellulose membranes. Blots were incubated with $\mathrm{N}$-terminal (Calbiochem) and C-terminal (00/2) PS1 antibodies.

\section{Sucrose gradients}

PS1 complexes were analysed by ultracentrifugation at $250,000 \times g$ in a continuous sucrose density gradient (5$20 \%$ ) for $4 \mathrm{hr}$ at $4^{\circ} \mathrm{C}$ in a Beckman TLS 55 rotor. CSF aliquots $(50 \mu \mathrm{L})$ were carefully loaded onto the top of the gradient containing $2 \mathrm{~mL}$ of $0.15 \mathrm{M} \mathrm{NaCl}, 50 \mathrm{mM} \mathrm{MgCl}$ and $0.5 \%$ Brij 97, in $50 \mathrm{mM}$ Tris- $\mathrm{HCl}$ (pH 7.4). After centrifugation $\sim 14$ fractions were gently collected from the top of the tubes. Enzyme markers of known sedimentation coefficient, $\beta$-galactosidase, catalase and alkaline phosphatase were used in the gradients to determine the approximate sedimentation coefficients.

\section{Measurement of $\boldsymbol{\gamma}$-secretase-mediated peptide cleavage}

$\gamma$-Secretase activity was assayed as reported elsewhere [17] using an intramolecularly quenched fluorogenic peptide probe, in the absence or presence of the $\gamma$ secretase inhibitor L-685,458 $(10 \mu \mathrm{M})$. Membranes prepared from human brain solubilized in assay buffer containing 1\% CHAPSO were used as positive controls [17]. Background fluorescence of the peptide probe was subtracted from all readings.

\section{Measurement of T-tau, P-tau and A $\beta 42$ by ELISA}

Total tau (T-tau), phosphorylated tau (P-tau) and A $31-42$ $(\mathrm{A} \beta 42)$ in CSF were determined using specific enzymelinked immunosorbent assays (ELISA) (Innogenetics, Ghent, Belgium).

\section{Statistical analysis}

All data were analyzed in SigmaStat (Version 2.0; SPSS Inc.) by Student's $t$ test (two-tailed) or Mann-Whitney $U$ test for single pair-wise comparisons and determination of exact $p$ values. Results are presented as means \pm SEM. Correlation between variables was assessed by linear regression analyses. $p$ values $<0.05$ were considered significant.

This study was approved by the ethics committee of the Miguel Hernandez University and was carried out in accordance with the Declaration of Helsinki.

\section{Abbreviations}

A $\beta$ : $\beta$-amyloid peptide; A 342 : A 1-42; AD: Alzheimer's disease; APH1: anterior pharynx-defective 1; BACE1: beta-site APP cleaving enzyme 1; CTF: C-terminal fragment; CSF: Cerebrospinal fluid; NDC: Non-demented control; NTF: N-terminal fragment; PEN-2: Presenilin enhancer 2; PS1: Presenilin-1; PS2: Presenilin-2; P-tau: Hyperphosphorylated tau; SEM: Standard error of mean; T-tau: Total tau.

\section{Competing interests}

All authors have contributed to the work and agree with the presented findings MSGA and JSV submitted a patent application for the use of PS1 complexes as an AD biomarker, as described herein. Appropriate procedures were followed to obtain approval from local ethics committees.

\section{Authors' contributions}

MSGA designed experiments, generated and analyzed data (WB, native electrophoresis, ultracentrifugation). MLC generated and analyzed data (WB IP and $\gamma$-secretase activity assay). GB generated and analyzed data (IP and ELISA). AR provided brain and post mortem CSF samples. JA provided freshly collected ante-mortem CSF samples. CAS provided PS1 CKO mice material and tested antibodies. NA provided CSF samples from AD and control subjects and supplied clinical data. KB designed experiments. JSV designed experiments, analyzed data and wrote the manuscript. All the authors participated in the preparation of the manuscript. All the authors contributed to the discussion of results and participated in the preparation of the manuscript. All authors read and approved the final manuscript.

\section{Acknowledgments}

We thank Dr. J. Culvenor and G. Evin (Department of Pathology, The University of Melbourne, Australia) for advice and the generous gift of PS1 antibodies. We also thank Dr. I. Torres-Aleman and L. Guinea (Cajal Institute, Madrid, Spain) for technical assistance in mouse CSF extraction; Ana Belen Rebolledo (Fundación Hospital Alcorcón, Madrid, Spain) for helping us to obtain post-mortem CSF samples and Dr. José Francisco Sánchez (Hospital General Universitario Elche, Spain) for assistance with lumbar CSF samples. This work was supported by grants from Fundación CIEN-Reina Sofía, FIS (PS09/00684; PI11/03026) and CIBERNED, ISC-III from Spain to JSV, and FIS (CP11/00312) to MSGA; and is part of the BIOMARKAPD Project in the frame of the Joint Programming Neurodegenerative Disease (JPND). MLC is supported by a Consolider-Predoctoral fellowship from the CSIC, Spain, cofinanced by the Fondo Social Europeo (FSE), E.C.

\section{Author details}

${ }^{1}$ Instituto de Neurociencias de Alicante, Universidad Miguel Hernández-CSIC, Av. Ramón y Cajal s/n, Sant Joan d'Alacant E-03550 Spain. ${ }^{2}$ Centro de Investigación Biomédica en Red sobre Enfermedades Neurodegenerativas (CIBERNED), Barcelona, Spain. ${ }^{3}$ Unidad de Investigación, Hospital General Universitario de Elche, FISABIO, 03203 Elche, Spain. ${ }^{4}$ Department of Psychiatry and Neurochemistry, Institute of Neuroscience and Physiology, Sahlgrenska Academy at University of Gothenburg, 43180 Mölndal, Sweden.

${ }^{5}$ Banco de Tejidos de la Fundación CIEN, CIEN Foundation, Carlos III Institute of Health, Alzheimer Center Reina Sofia Foundation, 28006 Madrid, Spain.

${ }^{6}$ Memory Clinic, Neurology Service, Hospital General Universitario de Elche, 03203 Elche, Spain. ${ }^{7}$ Institut de Neurociències, Departament Bioquímica i Biologia Molecular, Universitat Autònoma de Barcelona, 08193 Bellaterra, Spain. ${ }^{8}$ Karolinska Institute-Alzheimer Disease Research center, 17177 Stockholm, Sweden. 
Received: 3 August 2013 Accepted: 4 August 2013

Published: 6 August 2013

\section{References}

1. Blennow K, de Leon MJ, Zetterberg H: Alzheimer's disease. Lancet 2006, 368:387-403.

2. Thinakaran $\mathrm{G}, \mathrm{Koo} \mathrm{EH}$ : Amyloid precursor protein trafficking, processing, and function. J Biol Chem 2008, 283:29615-29619.

3. Vassar R, Kovacs DM, Yan R, Wong PC: The beta-secretase enzyme BACE in health and Alzheimer's disease: regulation, cell biology, function, and therapeutic potential. J Neurosci 2009, 29:12787-12794.

4. Holsinger RM, McLean CA, Collins SJ, Masters CL, Evin G: Increased betaSecretase activity in cerebrospinal fluid of Alzheimer's disease subjects. Ann Neurol 2004, 55:898-899.

5. Kaether C, Haass C, Steiner H: Assembly, trafficking and function of gamma-secretase. Neurodegener Dis 2006, 3:275-283.

6. Laudon $\mathrm{H}$, Hansson EM, Melén K, Bergman A, Farmery MR, Winblad B, Lendahl U, von Heijne G, Näslund J: A nine-transmembrane domain topology for presenilin 1. J Biol Chem 2005, 280:35352-35360.

7. Yu G, Chen F, Levesque G, Nishimura M, Zhang DM, Levesque L, Rogaeva E, Xu D, Liang Y, Duthie M, St George-Hyslop PH, Fraser PE: The presenilin 1 protein is a component of a high molecular weight intracellular complex that contains beta-catenin. J Biol Chem 1998, 273:16470-16475.

8. Thinakaran G, Borchelt DR, Lee MK, Slunt HH, Spitzer L, Kim G, Ratovitsky T, Davenport F, Nordstedt C, Seeger M, Hardy J, Levey Al, Gandy SE, Jenkins NA, Copeland NG, Price DL, Sisodia SS: Endoproteolysis of presenilin 1 and accumulation of processed derivatives in vivo. Neuron 1996, 17:181-190.

9. Podlisny MB, Citron M, Amarante P, Sherrington R, Xia W, Zhang J, Diehl T, Levesque G, Fraser P, Haass C, Koo EH, Seubert P, St George-Hyslop P, Teplow DB, Selkoe DJ: Presenilin proteins undergo heterogeneous endoproteolysis between Thr291 and Ala299 and occur as stable N- and C-terminal fragments in normal and Alzheimer brain tissue. Neurobiol Dis 1997, 3:325-337.

10. Capell A, Grünberg J, Pesold B, Diehlmann A, Citron M, Nixon R, Beyreuther K, Selkoe DJ, Haass C: The proteolytic fragments of the Alzheimer's disease-associated presenilin-1 form heterodimers and occur as a 100150-kDa molecular mass complex. J Biol Chem 1998, 273:3205-3211.

11. Kovacs DM, Fausett HJ, Page KJ, Kim TW, Moir RD, Merriam DE, Hollister RD, Hallmark OG, Mancini R, Felsenstein KM, Hyman BT, Tanzi RE, Wasco W: Alzheimer-associated presenilins 1 and 2: neuronal expression in brain and localization to intracellular membranes in mammalian cells. Nat Med 1996, 2:224-229.

12. De Strooper B, Beullens M, Contreras B, Levesque L, Craessaerts K, Cordell B, Moechars D, Bollen M, Fraser P, George-Hyslop PS, Van Leuven F: Phosphorylation, subcellular localization, and membrane orientation of the Alzheimer's disease-associated presenilins. J Biol Chem 1997, 272:3590-3598.

13. Silveyra MX, Evin G, Montenegro MF, Vidal CJ, Martínez S, Culvenor JG, SáezValero J: Presenilin-1 interacts with acetylcholinesterase and alters its enzymatic activity and glycosylation. Mol Cell Biol 2008, 28:2908-2919.

14. Nyabi O, Bentahir M, Horré K, Herreman A, Gottardi-Littell N, Van Broeckhoven C, Merchiers P, Spittaels K, Annaert W, De Strooper B: Presenilins mutated at Asp-257 or Asp-385 restore Pen-2 expression and Nicastrin glycosylation but remain catalytically inactive in the absence of wild type Presenilin. J Biol Chem 2003, 278:43430-43436

15. Kimberly WT, LaVoie MJ, Ostaszewski BL, Ye W, Wolfe MS, Selkoe DJ: Gamma-secretase is a membrane protein complex comprised of presenilin, nicastrin, Aph-1, and Pen-2. Proc Natl Acad Sci USA 2003, 100:6382-6387.

16. Edbauer D, Winkler $E$, Haass C, Steiner H: Presenilin and nicastrin regulate each other and determine amyloid beta-peptide production via complex formation. Proc Natl Acad Sci USA 2002, 99:8666-8671.

17. Farmery MR, Tjernberg LO, Pursglove SE, Bergman A, Winblad B, Näslund J: Partial purification and characterization of gamma-secretase from postmortem human brain. J Biol Chem 2003, 278:24277-24284.

18. Saura CA, Servián-Morilla E, Scholl FG: Presenilin/ $Y$-secretase regulates neurexin processing at synapses. PLoS One 2011, 6:e19430.

19. Zhong Z, Ewers M, Teipel S, Bürger K, Wallin A, Blennow K, He P, McAllister C, Hampel H, Shen Y: Levels of beta-secretase (BACE1) in cerebrospinal fluid as a predictor of risk in mild cognitive impairment. Arch Gen Psychiatry 2007, 64:718-726.
20. Zetterberg H, Andreasson U, Hansson O, Wu G, Sankaranarayanan S, Andersson ME, Buchhave P, Londos E, Umek RM, Minthon L, Simon AJ, Blennow K: Elevated cerebrospinal fluid BACE1 activity in incipient Alzheimer disease. Arch Neurol 2008, 65:1102-1107.

21. Mulder SD, van der Flier WM, Verheijen JH, Mulder C, Scheltens P, Blankenstein MA, Hack CE, Veerhuis R: BACE1 activity in cerebrospinal fluid and its relation to markers of AD pathology. J Alzheimers Dis 2010, 20:253-260

22. Verheijen JH, Huisman LG, van Lent N, Neumann U, Paganetti P, Hack CE, Bouwman F, Lindeman J, Bollen EL, Hanemaaijer R: Detection of a soluble form of BACE-1 in human cerebrospinal fluid by a sensitive activity assay. Clin Chem 2006, 52:1168-1174.

23. Benussi L, Alberici A, Mayhaus M, Langer U, Ghidoni R, Mazzoli F, Nicosia F, Barbiero L, Frisoni G, Zanetti O, Gasparini L, Nitsch RM, Binetti G: Detection of the presenilin $1 \mathrm{COOH}$-terminal fragment in the extracellular compartment: a release enhanced by apoptosis. Exp Cell Res 2001, 269:256-265.

24. Yamamoto A, Sahara N, Usami M, Okochi M, Kondo T, Kametani F, Tanaka K, Yahagi Y, Shirasawa T, Itoyama Y, Mori H: Abnormal gel-electrophoretic behavior of presenilin 1 and it's fragment. Biochem Biophys Res Commun 1996, 226:536-541.

25. Busciglio J, Hartmann H, Lorenzo A, Wong C, Baumann K, Sommer B, Staufenbiel M, Yankner BA: Neuronal localization of presenilin-1 and association with amyloid plaques and neurofibrillary tangles in Alzheimer's disease. J Neurosci 1997, 17:5101-5107.

26. Chyung JH, Raper DM, Selkoe DJ: Gamma-secretase exists on the plasma membrane as an intact complex that accepts substrates and effects intramembrane cleavage. J Biol Chem 2005, 280:4383-4392.

27. Sato T, Diehl TS, Narayanan S, Funamoto S, Ihara $Y$, De Strooper B, Steiner $H_{\text {, }}$ Haass C, Wolfe MS: Active gamma-secretase complexes contain only one of each component. J Biol Chem 2007, 282:33985-33993.

28. Hébert SS, Godin C, Lévesque G: Oligomerization of human presenilin-1 fragments. FEBS Lett 2003, 550:30-34.

29. Wolfe MS: Gamma-Secretase inhibitors as molecular probes of presenilin function. J Mol Neurosci 2001, 17:199-204.

30. Chung HM, Struhl G: Nicastrin is required for Presenilin-mediated transmembrane cleavage in Drosophila. Nat Cell Biol 2001, 3:1129-1132.

31. Edbauer D, Winkler E, Regula JT, Pesold B, Steiner $H$, Haass C: Reconstitution of gamma-secretase activity. Nat Cell Biol 2003, 5:486-488

32. Saura CA, Tomita T, Davenport F, Harris CL, Iwatsubo T, Thinakaran G: Evidence that intramolecular associations between presenilin domains are obligatory for endoproteolytic processing. J Biol Chem 1999, 274:13818-13823.

33. Barão $S$, Zhou L, Adamczuk K, Vanhoutvin T, van Leuven F, Demedts $D$ Vijverman AC, Vijverman AC, Bossuyt X, Vandenberghe R, De Strooper B: BACE1 Levels Correlate With Phospho-Tau Levels In Human Cerebrospinal Fluid. Curr Alzheimer Res 2013. Apr 8. [Epub ahead of print].

34. Borghi R, Piccini A, Barini E, Cirmena G, Guglielmotto M, Tamagno E, Fornaro M, Perry G, Smith MA, Garuti A, Tabaton M: Upregulation of presenilin 1 in brains of sporadic, late-onset Alzheimer's disease. J Alzheimers Dis 2010, 22:771-775.

35. Kakuda N, Shoji M, Arai H, Furukawa K, Ikeuchi T, Akazawa K, Takami M, Hatsuta H, Murayama S, Hashimoto Y, Miyajima M, Arai H, Nagashima Y, Yamaguchi $H$, Kuwano R, Nagaike $K$, Ihara $Y$ : Altered $\gamma$-secretase activity in mild cognitive impairment and Alzheimer's disease. EMBO Mol Med 2012, 4:344-352.

36. Mathews PM, Cataldo AM, Kao BH, Rudnicki AG, Qin $X$, Yang JL, Jiang $Y$, Picciano M, Hulette C, Lippa CF, Bird TD, Nochlin D, Walter J, Haass C, Lévesque $L$, Fraser PE, Andreadis A, Nixon RA: Brain expression of presenilins in sporadic and early-onset, familial Alzheimer's disease. Mol Med 2000, 6:878-891.

37. Davidsson P, Bogdanovic N, Lannfelt L, Blennow K: Reduced expression of amyloid precursor protein, presenilin-1 and rab3a in cortical brain regions in Alzheimer's disease. Dement Geriatr Cogn Disord 2001, 12:243-250.

38. Verdile G, Gnjec A, Miklossy J, Fonte J, Veurink G, Bates K, Kakulas B, Mehta PD, Milward EA, Tan N, Lareu R, Lim D, Dharmarajan A, Martins RN: Protein markers for Alzheimer disease in the frontal cortex and cerebellum. Neurology 2004, 63:1385-1392.

39. Johnston JA, Froelich S, Lannfelt L, Cowburn RF: Quantification of presenilin-1 mRNA in Alzheimer's disease brains. FEBS Lett 1996 394:279-284. 
40. Ikeda K, Urakami K, Arai H, Wada K, Wakutani Y, Ji Y, Adachi Y, Okada A, Kowa H, Sasaki H, Ohno K, Ohtsuka Y, Ishikawa Y, Nakashima K: The expression of presenilin $1 \mathrm{mRNA}$ in skin fibroblasts and brains from sporadic Alzheimer's disease. Dement Geriatr Cogn Disord 2000, 11:245-250.

41. Silveyra MX, García-Ayllón MS, Serra-Basante C, Mazzoni V, García-Gutierrez MS, Manzanares J, Culvenor JG, Sáez-Valero J: Changes in acetylcholinesterase expression are associated with altered presenilin-1 levels. Neurobiol Aging 2012, 33:627.e27-37.

42. Lee MK, Slunt HH, Martin L, Thinakaran G, Kim G, Gandy SE, Seeger M, Koo E, Price DL, Sisodia SS: Expression of presenilin 1 and 2 (PS1 and PS2) in human and murine tissues. J Neurosci 1996, 16:7513-7525.

43. Nilsberth C, Luthman J, Lannfelt L, Schultzberg M: Expression of presenilin 1 mRNA in rat peripheral organs and brain. Histochem J 1999, 31:515-523.

44. Blennow K: Biomarkers in Alzheimer's disease drug development. Nat Med 2010, 16:1218-1222.

45. Blennow K, Hampel H: CSF markers for incipient Alzheimer's disease. Lancet Neurol 2003, 2:605-613.

46. Selkoe DJ, Wolfe MS: Presenilin: running with scissors in the membrane. Cell 2007, 131:215-221.

47. Bergmans BA, De Strooper B: Gamma-secretases: from cell biology to therapeutic strategies. Lancet Neurol 2010, 9:215-226.

48. Mirra SS, Gearing M, McKeel DW Jr, Crain BJ, Hughes JP, van Belle G, Heyman A: Interlaboratory comparison neuropathology assessments in Alzheimer's disease: a study of the Consortium to Establish a Registry of Alzheimer's Disease (CERAD). J Neuropath Exp Neurol 1994, 53:303-315.

49. McKhann G, Drachman D, Folstein M, Katzman R, Price D, Stadlan EM: Clinical diagnosis of Alzheimer's disease: report of the NINCDSADRDAWork Group under the auspices of Department of Health and Human Services Task Force on Alzheimer's Disease. Neurology 1984, 34:939-944.

50. Yu H, Saura CA, Choi SY, Sun LD, Yang X, Handler M, Kawarabayashi T, Younkin L, Fedeles B, Wilson MA, Younkin S, Kandel ER, Kirkwood A, Shen J: APP processing and synaptic plasticity in presenilin-1 conditional knockout mice. Neuron 2001, 31:713-726.

51. Sáez-Valero J, de Gracia JA, Lockridge O: Intraperitoneal administration of $340 \mathrm{kDa}$ human plasma butyrylcholinesterase increases the level of the enzyme in the cerebrospinal fluid of rats. Neurosci Lett 2005, 383:93-98.

52. Culvenor JG, Maher F, Evin G, Malchiodi-Albedi F, Cappai R, Underwood JR, Davis JB, Karran EH, Roberts GW, Beyreuther K, Masters CL: Alzheimer's disease-associated presenilin 1 in neuronal cells: evidence for localization to the endoplasmic reticulum-Golgi intermediate compartment. J Neurosci Res 1997, 49:719-731.

53. Schägger $\mathrm{H}$, von Jagow $\mathrm{G}$ : Blue native electrophoresis for isolation of membrane protein complexes in enzymatically active form. Anal Biochem 1991, 199:223-231.

54. Evin G, Sharples RA, Weidemann A, Reinhard FB, Carbone V, Culvenor JG Holsinger RM, Sernee MF, Beyreuther K, Masters CL: Aspartyl protease inhibitor pepstatin binds to the presenilins of Alzheimer's disease. Biochemistry 2001, 40:8359-8368.

55. Culvenor JG, llaya NT, Ryan MT, Canterford L, Hoke DE, Williamson NA, McLean CA, Masters CL, Evin G: Characterization of presenilin complexes from mouse and human brain using Blue Native gel electrophoresis reveals high expression in embryonic brain and minimal change in complex mobility with pathogenic presenilin mutations. Eur J Biochem 2004, 271:375-385.

doi:10.1186/2051-5960-1-46

Cite this article as: García-Ayllón et al: CSF Presenilin-1 complexes are increased in Alzheimer's disease. Acta Neuropathologica Communications 2013 1:46.

\section{Submit your next manuscript to BioMed Central and take full advantage of:}

- Convenient online submission

- Thorough peer review

- No space constraints or color figure charges

- Immediate publication on acceptance

- Inclusion in PubMed, CAS, Scopus and Google Scholar

- Research which is freely available for redistribution

Submit your manuscript at www.biomedcentral.com/submit
Ciomed Central 